\title{
Impact of Organic and Inorganic Sources of Nitrogen and Water Management on Tomato-French Bean by Radish Cropping System
}

\author{
A. Yumnam ${ }^{1 *}$, A.R. Mandal $^{2}$, T.M. Singh ${ }^{3}$ and N. Surbala Devi ${ }^{4}$ \\ ${ }^{1}$ Department of Horticulture, ${ }^{4}$ Department of Soil Science, College of Agriculture, Central \\ Agricultural University, Imphal, India \\ ${ }^{2}$ Department of vegetable Crops, Faculty of Hoticulture, BCKV, West Bengal, India \\ ${ }^{3}$ KVK, Chandel, ICAR, NEHR, Imphal Centre, India \\ *Corresponding author
}

\begin{tabular}{|l|}
\hline K e y w o r d s \\
Irrigation, Fertility \\
level, Cropping \\
system, Tomato, \\
$\begin{array}{l}\text { French bean, } \\
\text { Raddish, Yield. }\end{array}$ \\
\hline Article Info \\
\hline $\begin{array}{l}\text { Accepted: } \\
\text { 28 October } 2017 \\
\text { Available Online: } \\
\text { 10 December } 2017\end{array}$
\end{tabular}

\section{Introduction}

Vegetables occupy an important place in crop diversification and play a key role in economic security of our country. The share of vegetables in area and production was $0.39 \%$ and $60.84 \%$, respectively. In vegetable production, India secured second position in the world after China with an annual production of 115.01 million tonnes from an area of 7.58 million hectare during 2007-2008 with the productivity of 15.2 metric tonnes per hectare (NHB, 2008). Though West Bengal continues to be the leading state in area and production, the productivity is higher in Tamil Nadu followed by U.P. and Bihar. The vegetable production is around 1 billion tonnes with an average productivity of 15.1 
tonnes per hectare. However, this is much lesser than the recommended requirement of $300 \mathrm{~g} / \mathrm{capita} /$ day of vegetables for a balanced diet. Therefore, productivity of vegetables needs to be raised to 25 tonnes per hectare, as there is a tremendous pressure on land and renewable energy sources to meet everincreasing demand of quality vegetables (Anon., 2006). In India, fertilizer being relatively cheap in relation to the value of the crop, farmers tend to apply too much fertilizer. This is particularly true for vegetables, since they are a high-value crop. For the farmer, this represents a type of insurance against crop losses due to nutrient deficiencies. However, overuse of fertilizer is not only wasteful, but is damaging crop quality and soil health in particular and the environment in general. Application of required amount of nutrients is one of the best methods for gaining higher yield of any crop.

Most of the vegetable crops are annuals and short duration in nature. Growths of vegetable crops are rapid and they are harvested in immature stage. Therefore, fertilizers and manures in adequate quantities are required to promote proper growth with a view to achieve success in vegetable production. Similarly, plants need water continuously during their life. It profoundly influences photosynthesis, respiration, absorption, translocation and utilization of mineral nutrients, and cell division besides some other metabolic processes. In India, the irrigation source is scarce compared to cropped area. So, it is advisable to use irrigation water wisely and economically at proper time and in required quantity. It would, therefore, necessary to establish a balance between number of irrigations and yield in such a way that maximum yield per unit of water used by the crop is obtained i.e., maximum water use efficiency. Among the different farming practices, irrigation management is very important for proper growth and yield of any crop, but either excess or shortage of water seriously affects the same. The relationship between growth and yield of a crop and water use has been a major focus of agricultural research in the arid and semi- arid regions. Most vegetables are rather shallow rooted and even short periods of two to three days of stress can affect marketable yield. Irrigation is important to increase size and weight of individual fruit and to prevent defects such as toughness, strong flavor, poor pod filling, and cracking of edible parts, blossom - end rot and misshapen fruit. Considering the above in view, proper management of water is very much essential for good yields and high quality of any vegetable. Intercropping is a cropping system where two or more crops are grown simultaneously in alternate rows or otherwise in the same land showing significant amount of intercrop competition.

The crop may or may not be sown/planted and harvested at one time. Intercropping is the only possible way of increasing cropping intensity to utilize available resources efficiently. Recently intercropping has been recognized as a potential beneficial system of crop production. The main purpose of intercropping is to get more net return per unit area of land at the same time with saving of energy and water along with less expenditure involving cost of cultivation.

The technology of intercropping of vegetable crops in the same piece of land at the same time could give a new direction in increasing total production with available resources, thereby raising farm family income. Therefore, keeping the above discussions as guideline, the present study was undertaken with vegetable based cropping system (using vegetables like tomato, French bean, radish, as experimental crops) under different sources of nitrogen with adequate and limited supplies of water. 


\section{Materials and Methods}

The experiments were conducted at the Horticultural Research Station, Mondouri, Bidhan Chandra Krishi Viswavidyalaya, Mohanpur, Nadia, West Bengal during the year 2007-08 and 2008-09. The experiment was laid out in split plot design with 18 treatments and 3 replications. The treatment comprised of Irrigation $\left(\mathrm{I}_{1}-15 \mathrm{CPE}, \mathrm{I}_{2}-30\right.$ $\left.\mathrm{CPE}, \mathrm{I}_{3}-45 \mathrm{CPE}\right)$; Cropping system $\left(\mathrm{C}_{1}-\right.$ Sole crop, $\mathrm{C}_{2}-$ Intercrops); Fertility level ( $\mathrm{F}_{1}$ $-100 \% \mathrm{~N} / \mathrm{ha}$ from inorganic source, $\mathrm{F}_{2}-75 \%$ $\mathrm{N} /$ ha from inorganic source $+25 \% \mathrm{~N} /$ ha from organic source, $\mathrm{F}_{3}-50 \% \mathrm{~N} /$ ha from inorganic source $+50 \% \mathrm{~N} /$ ha from organic source. Tomato seedlings were transplanted as a main crop at a spacing of $120 \times 60 \mathrm{~cm}$ between and within rows. French bean seeds were sown as an intercrops at a distance of 30 $\mathrm{cm}$ in hills $60 \mathrm{~cm}$ apart and to a depth of 2.5 $3.0 \mathrm{~cm}$ in the main field. Radish seeds were also sown continuously in line in the main field and after thinning a spacing of $10 \mathrm{~cm}$ from plant to plant and $20 \mathrm{~cm}$ between rows were maintained. Irrigations were given by using cumulative pan evaporation (CPE). The water level in every irrigation was maintained till saturated (i.e. $5 \mathrm{~cm}$ ). Earthing up was done at 30 days after planting and ridges were made by manually with the help of a spade. This operation also kept the field weed free by helping the crop to attain a good crop canopy. In order to keep the crops free from diseases and insect pests, adequate plant protection measures were taken in time. Observation was recorded on yield and its attributes from each treatment.

\section{Results and Discussion}

Effect of levels of irrigation, cropping system and fertility level of tomato

Data presented in Table 1 reveal that effect of interactions of irrigation, cropping system and fertility had significant influence on the results of plant height. Maximum plant height of 82.85 and $80.45 \mathrm{~cm}$ were obtained with $\mathrm{I}_{2} \mathrm{C}_{1} \mathrm{~F}_{3}$ combination respectively in 2007-08 and 2008-09. The pooled values of the two consecutive years show that, the highest plant height of $81.65 \mathrm{~cm}$ was obtained with $\mathrm{I}_{2} \mathrm{C}_{1} \mathrm{~F}_{3}$ combination. Effect of interactions of irrigation, cropping system and fertility was significant on number of fruits per plant (Table 1). Treatment combination $\mathrm{I}_{2} \mathrm{C}_{1} \mathrm{~F}_{2}$ produced maximum number of fruits per plant of 27.52 and 28.34 respectively in first and second year. This combination differed statistically from other interactions except $\mathrm{I}_{3} \mathrm{C}_{1} \mathrm{~F}_{2}$ in 2007 - 08. Minimum number of fruits per plant was recorded with $\mathrm{I}_{1} \mathrm{C}_{2} \mathrm{~F}_{3}$ in both the years. Pooled data indicate that number of fruits ranged between 17.69 in $\mathrm{I}_{1} \mathrm{C}_{2} \mathrm{~F}_{3}$ and 27.93 in $\mathrm{I}_{2} \mathrm{C}_{1} \mathrm{~F}_{2}$. Treatment combinations $\mathrm{I}_{2} \mathrm{C}_{1} \mathrm{~F}_{1}, \mathrm{I}_{2} \mathrm{C}_{2} \mathrm{~F}_{2}$ and $\mathrm{I}_{3} \mathrm{C}_{1} \mathrm{~F}_{2}$ were also found to be promising with the production of more than 25 fruits per plant. Interactions of irrigation, cropping system and fertility resulted significant effect on fruit weight (Table 1). Treatment combination $\mathrm{I}_{2} \mathrm{C}_{1} \mathrm{~F}_{2}$ was found to be the superior performer recording maximum fruit weight of 74.41 and 69.75 g respectively in 2007-08 and 2008-09 followed by $\mathrm{I}_{2} \mathrm{C}_{2} \mathrm{~F}_{2}$ where the same were 72.48 and $68.46 \mathrm{~g}$. These two treatments were statistically at par for the results of fruit weight of tomato. Higher fruit weight of tomato under $F_{2}$ might be due to the fact that organic manures would have improved the soil physical conditions and increased nutrient availability resulting in a better vegetative frame (Rafi et al., 2005). The increase in fruit weight of tomato due to integrated nutrient management was reported earlier by Shukla $e t$ al., (2009). Beneficial effects of nitrogen in improvement of this character in tomato were also reported by Gupta and Sengar, (2000), Sahoo et al., (2002) and Kaur et al., (2003). Minimum fruit weight of 42.51 and $38.67 \mathrm{~g}$ were obtained with $\mathrm{I}_{1} \mathrm{C}_{2} \mathrm{~F}_{3}$ combination in the 
respective years. Pooled data show that highest $(72.08 \mathrm{~g})$ and lowest $(40.59 \mathrm{~g})$ fruit weight were obtained respectively with $\mathrm{I}_{2} \mathrm{C}_{1} \mathrm{~F}_{2}$ and $\mathrm{I}_{1} \mathrm{C}_{2} \mathrm{~F}_{3}$ combinations. Interactions of irrigation, cropping system and fertility rendered their significant effect on fruit yield per hectare (Table 1). Treatment combination $\mathrm{I}_{2} \mathrm{C}_{1} \mathrm{~F}_{2}$ was found to be significantly superior recording fruit yield of 28.86 and 27.58 t/ha respectively in 2007-08 and 2008-09. The fruit yield decreased significantly at $\mathrm{I}_{1}$ level of irrigation (15 CPE). This may be explained from the findings of Sharda et al., (2006) in onion who reported that yield at higher level of irrigation decreased significantly and might be due to the fact that with increase water supply, the increase in evapotranspiration was proportionally higher than the increase in yield upto certain limits. Higher and lower proportions of inorganic $\mathrm{N}$ in the fertility treatments in this experiment were not effective for getting better fruit yield of tomato. Better results under $F_{2}$ were perhaps due to higher plant height, number, weight of fruit. Increase yield was also due to higher absorption of $\mathrm{N}, \mathrm{P}$, and $\mathrm{K}$, this might have favourably affected the chlorophyll content of leaves resulting in increased synthesis of carbohydrates and buildup of new cells (Harikrishna et al., 2002). Besides organic manures in terms of FYM in combination with inorganic fertilizers improved the soil physical conditions and increased nutrient availability resulting increased yield of tomato (Rafi et al., 2005). Improved biometric characters namely plant height, number of branches, number and weight of fruit, possibly contributed to the higher fruit yield per hectare under the said combination.

Pooled data indicate that fruit yield ranged between $12.56 \mathrm{t} / \mathrm{ha}$ in $\mathrm{I}_{1} \mathrm{C}_{2} \mathrm{~F}_{3}$ and $28.22 \mathrm{t} / \mathrm{ha}$ in $\mathrm{I}_{2} \mathrm{C}_{1} \mathrm{~F}_{2}$. Yield of tomato under intercropping was less than sole crop. Lower yield of tomato under intercropping was possibly due to competition for space, light, water and nutrients created by intercrops namely French bean and radish. Prakash et al., (2004) recorded higher yield of sole crop (tomato) than intercrop. Treatment combinations viz., $\mathrm{I}_{2} \mathrm{C}_{2} \mathrm{~F}_{2}$ and $\mathrm{I}_{3} \mathrm{C}_{1} \mathrm{~F}_{2}$ were also found to be promising recording more than 25.00 tonnes fruit yield per hectare. Data presented in Table 2 reveal that ascorbic acid content in fruit of tomato significantly varied due to different treatments. The significant impact on the ascorbic acid content in fruit in both the years with combined influence of different treatments was observed. The pooled data showed that significantly highest amount of ascorbic acid content was exerted in $\mathrm{I}_{2} \mathrm{C}_{2} \mathrm{~F}_{3}$ combination with a value of $24.35 \mathrm{mg} / 100 \mathrm{~g}$. Treatment combinations rendered significant influence on lycopene content in fruits of tomato (Table 2). Revelation of the results indicates that significantly highest amount $(3.37 \mathrm{mg} / 100 \mathrm{~g})$ was noted in $\mathrm{I}_{2} \mathrm{C}_{1} \mathrm{~F}_{3}$ treatment combination during first year. However, in second year it was observed under $\mathrm{I}_{1} \mathrm{C}_{2} \mathrm{~F}_{2}$ with $3.26 \mathrm{mg} / 100 \mathrm{~g}$. Nitrogen content in fruit significantly varied due to different treatment combinations (Table 2). Treatment combination $\mathrm{I}_{2} \mathrm{C}_{1} \mathrm{~F}_{1}$ showed significantly highest amount of $4.82 \%$ Nitrogen accumulation in fruit in second year while in first year it was observed under $\mathrm{I}_{2} \mathrm{C}_{2} \mathrm{~F}_{1}$ combination with a value of $4.77 \%$. Like the Nitrogen content in fruit, the Nitrogen uptake produced more or less same trend (Table 2). Different treatment combinations produced significantly increased Nitrogen uptake by fruit of tomato. Revelation of the results indicates that significantly highest amount of $\mathrm{N}$ uptake by fruit $(21.92 \mathrm{Kg} / \mathrm{ha})$ was observed with $\mathrm{I}_{2} \mathrm{C}_{1} \mathrm{~F}_{1}$.

\section{Effect of levels of irrigation and fertility level of French bean}

Effect of interactions of irrigation and fertility level was statistically significant on plant height of French bean. 
Table.1 Effect of levels of irrigation, cropping system and fertility level on plant height, no. of fruits/ plant, fruit weight, fruit yield of tomato

\begin{tabular}{|c|c|c|c|c|c|c|c|c|c|c|c|c|}
\hline \multirow{2}{*}{$\begin{array}{c}\text { Treatment } \\
\text { combinations }\end{array}$} & \multicolumn{3}{|c|}{ Plant height (cm) } & \multicolumn{3}{|c|}{ No. of fruits / plant } & \multicolumn{3}{|c|}{ Fruit weight (g) } & \multicolumn{3}{|c|}{ Fruit yield (t / ha) } \\
\hline & 07-08 & 08-09 & Pooled & $07-08$ & $08-09$ & Pooled & $07-08$ & $08-09$ & Pooled & $07-08$ & $08-09$ & Pooled \\
\hline $\mathrm{I}_{1} \mathrm{C}_{1} \mathrm{~F}_{1}$ & 65.82 & 63.52 & 64.67 & 19.21 & 20.76 & 19.99 & 56.68 & 54.67 & 55.68 & 15.30 & 16.08 & 15.69 \\
\hline $\mathrm{I}_{1} \mathrm{C}_{1} \mathrm{~F}_{2}$ & 69.67 & 68.23 & 68.95 & 21.22 & 21.19 & 21.21 & 56.85 & 55.21 & 56.03 & 17.34 & 16.56 & 16.95 \\
\hline $\mathrm{I}_{1} \mathrm{C}_{1} \mathrm{~F}_{3}$ & 59.25 & 60.52 & 59.89 & 18.07 & 19.25 & 18.66 & 51.72 & 49.62 & 50.67 & 13.28 & 13.67 & 13.47 \\
\hline $\mathrm{I}_{1} \mathrm{C}_{2} \mathrm{~F}_{1}$ & 63.21 & 61.03 & 62.12 & 20.34 & 22.32 & 21.33 & 49.37 & 45.75 & 47.56 & 14.13 & 14.28 & 14.21 \\
\hline $\mathrm{I}_{1} \mathrm{C}_{2} \mathrm{~F}_{2}$ & 69.13 & 67.52 & 68.33 & 22.27 & 24.54 & 23.40 & 64.27 & 59.69 & 61.98 & 20.25 & 20.71 & 20.48 \\
\hline $\mathrm{I}_{1} \mathrm{C}_{2} \mathrm{~F}_{3}$ & 59.62 & 58.46 & 59.04 & 17.16 & 18.21 & 17.69 & 42.51 & 38.67 & 40.59 & 12.64 & 12.47 & 12.56 \\
\hline $\mathrm{I}_{2} \mathrm{C}_{1} \mathrm{~F}_{1}$ & 79.36 & 78.38 & 78.87 & 24.15 & 26.43 & 25.29 & 70.21 & 67.42 & 68.82 & 23.65 & 24.98 & 24.32 \\
\hline $\mathrm{I}_{2} \mathrm{C}_{1} \mathrm{~F}_{2}$ & 82.85 & 80.45 & 81.65 & 27.52 & 28.34 & 27.93 & 74.41 & 69.75 & 72.08 & 28.86 & 27.58 & 28.22 \\
\hline $\mathrm{I}_{2} \mathrm{C}_{1} \mathrm{~F}_{3}$ & 59.48 & 57.61 & 58.55 & 22.87 & 24.52 & 23.70 & 63.32 & 59.38 & 61.35 & 20.43 & 20.61 & 20.52 \\
\hline $\mathrm{I}_{2} \mathrm{C}_{2} \mathrm{~F}_{1}$ & 63.41 & 61.22 & 62.32 & 24.32 & 23.82 & 24.07 & 65.52 & 61.42 & 63.47 & 22.39 & 20.98 & 21.69 \\
\hline $\mathrm{I}_{2} \mathrm{C}_{2} \mathrm{~F}_{2}$ & 82.67 & 78.02 & 80.35 & 26.53 & 27.16 & 26.85 & 72.48 & 68.46 & 70.47 & 27.10 & 26.76 & 26.93 \\
\hline $\mathrm{I}_{2} \mathrm{C}_{2} \mathrm{~F}_{3}$ & 58.61 & 56.75 & 57.68 & 20.34 & 22.31 & 21.33 & 62.38 & 57.76 & 60.07 & 17.90 & 18.11 & 18.01 \\
\hline $\mathrm{I}_{3} \mathrm{C}_{1} \mathrm{~F}_{1}$ & 63.48 & 61.47 & 62.48 & 22.46 & 23.16 & 22.81 & 63.22 & 59.31 & 61.26 & 20.22 & 19.67 & 19.95 \\
\hline $\mathrm{I}_{3} \mathrm{C}_{1} \mathrm{~F}_{2}$ & 75.08 & 71.46 & 73.27 & 27.45 & 26.98 & 27.22 & 68.19 & 63.47 & 65.83 & 26.40 & 24.41 & 25.41 \\
\hline $\mathrm{I}_{3} \mathrm{C}_{1} \mathrm{~F}_{3}$ & 58.43 & 58.42 & 58.43 & 20.71 & 21.15 & 20.93 & 58.25 & 55.17 & 56.71 & 17.27 & 16.63 & 16.95 \\
\hline $\mathrm{I}_{3} \mathrm{C}_{2} \mathrm{~F}_{1}$ & 63.47 & 61.48 & 62.48 & 21.32 & 22.32 & 21.82 & 64.72 & 60.72 & 62.72 & 19.39 & 19.14 & 19.27 \\
\hline $\mathrm{I}_{3} \mathrm{C}_{2} \mathrm{~F}_{2}$ & 73.72 & 70.22 & 71.97 & 23.39 & 24.43 & 23.91 & 66.38 & 63.18 & 64.78 & 21.93 & 21.58 & 21.75 \\
\hline $\mathrm{I}_{3} \mathrm{C}_{2} \mathrm{~F}_{3}$ & 55.72 & 53.35 & 54.54 & 18.21 & 19.33 & 18.77 & 56.72 & 52.67 & 54.70 & 14.62 & 14.47 & 14.55 \\
\hline $\mathrm{S} . \mathrm{E}(\mathrm{m}) \pm$ & 0.88 & 0.85 & 0.61 & 0.29 & 0.30 & 0.21 & 0.80 & 0.75 & 0.55 & 0.25 & 0.25 & 0.18 \\
\hline C.D. (0.05) & 2.54 & 2.45 & 1.73 & 0.84 & 0.87 & 0.59 & 2.31 & 2.17 & 1.56 & 0.72 & 0.72 & 0.51 \\
\hline
\end{tabular}

$\mathrm{I}_{1}=15 \mathrm{CPE} ; \mathrm{I}_{2}=30 \mathrm{CPE} ; \mathrm{I}_{3}=45 \mathrm{CPE} ; \mathrm{F}_{1}=100 \% \mathrm{~N} /$ ha from inorganic source; $\mathrm{F}_{2}=75 \% \mathrm{~N} /$ ha from inorganic source $+25 \% \mathrm{~N} /$ ha from organic source; $\mathrm{F}_{3}=50 \% \mathrm{~N} / \mathrm{ha}$ from inorganic source $+50 \% \mathrm{~N} /$ ha from organic source; $\mathrm{C}_{1}=$ Sole crop; $\mathrm{C}_{2}=$ Intercrop.

Table.2 Effect of levels of irrigation, cropping system and fertility level on ascorbic acid, lycopene content, Nitrogen content and Nitrogen uptake in tomato

\begin{tabular}{|c|c|c|c|c|c|c|c|c|c|c|c|c|}
\hline \multirow{2}{*}{$\begin{array}{c}\text { Treatment } \\
\text { combinations }\end{array}$} & \multicolumn{3}{|c|}{ Ascorbic acid (mg / 100 g) } & \multicolumn{3}{|c|}{ Lycopene (mg / 100 g) } & \multicolumn{3}{|c|}{ Nitrogen content in fruit $(\%)$} & \multicolumn{3}{|c|}{ Nitrogen uptake by fruit (kg / ha) } \\
\hline & 07-08 & 08-09 & Pooled & 07-08 & 08-09 & Pooled & 07-08 & 08-09 & Pooled & 07-08 & 08-09 & Pooled \\
\hline $\mathrm{I}_{1} \mathrm{C}_{1} \mathrm{~F}_{1}$ & 17.68 & 18.82 & 18.25 & 2.42 & 2.41 & 2.42 & 4.72 & 4.69 & 4.70 & 9.42 & 9.34 & 9.38 \\
\hline $\mathrm{I}_{1} \mathrm{C}_{1} \mathrm{~F}_{2}$ & 25.62 & 20.31 & 22.97 & 2.36 & 2.35 & 2.36 & 4.64 & 4.61 & 4.62 & 9.74 & 9.67 & 9.71 \\
\hline $\mathrm{I}_{1} \mathrm{C}_{1} \mathrm{~F}_{3}$ & 17.71 & 14.67 & 16.19 & 2.31 & 2.25 & 2.28 & 4.59 & 4.42 & 4.50 & 9.91 & 9.56 & 9.73 \\
\hline $\mathrm{I}_{1} \mathrm{C}_{2} \mathrm{~F}_{1}$ & 20.23 & 18.17 & 19.20 & 3.25 & 3.21 & 3.23 & 4.80 & 4.77 & 4.79 & 12.58 & 12.45 & 12.52 \\
\hline $\mathrm{I}_{1} \mathrm{C}_{2} \mathrm{~F}_{2}$ & 22.74 & 23.40 & 23.07 & 3.31 & 3.26 & 3.29 & 4.69 & 4.53 & 4.60 & 13.24 & 12.81 & 13.03 \\
\hline $\mathrm{I}_{1} \mathrm{C}_{2} \mathrm{~F}_{3}$ & 20.98 & 16.17 & 18.57 & 3.34 & 3.21 & 3.28 & 3.62 & 3.67 & 3.64 & 6.34 & 6.43 & 6.38 \\
\hline $\mathrm{I}_{2} \mathrm{C}_{1} \mathrm{~F}_{1}$ & 22.56 & 18.72 & 20.74 & 2.45 & 2.44 & 2.45 & 4.77 & 4.82 & 4.80 & 21.78 & 22.06 & 21.92 \\
\hline $\mathrm{I}_{2} \mathrm{C}_{1} \mathrm{~F}_{2}$ & 24.28 & 22.04 & 23.16 & 2.31 & 2.34 & 2.33 & 4.62 & 4.67 & 4.64 & 18.80 & 18.96 & 18.88 \\
\hline $\mathrm{I}_{2} \mathrm{C}_{1} \mathrm{~F}_{3}$ & 17.85 & 15.00 & 16.23 & 3.37 & 2.35 & 2.86 & 4.60 & 4.63 & 4.61 & 11.26 & 11.33 & 11.30 \\
\hline $\mathrm{I}_{2} \mathrm{C}_{2} \mathrm{~F}_{1}$ & 19.01 & 18.62 & 18.82 & 3.32 & 2.23 & 2.78 & 4.82 & 4.80 & 4.81 & 13.37 & 13.29 & 13.33 \\
\hline $\mathrm{I}_{2} \mathrm{C}_{2} \mathrm{~F}_{2}$ & 20.21 & 16.17 & 18.19 & 2.22 & 2.17 & 2.20 & 4.64 & 4.61 & 4.62 & 14.77 & 14.67 & 14.72 \\
\hline $\mathrm{I}_{2} \mathrm{C}_{2} \mathrm{~F}_{3}$ & 25.37 & 23.34 & 24.35 & 2.18 & 2.12 & 2.15 & 3.59 & 3.60 & 3.60 & 7.38 & 7.42 & 7.40 \\
\hline $\mathrm{I}_{3} \mathrm{C}_{1} \mathrm{~F}_{1}$ & 22.72 & 18.67 & 20.69 & 2.16 & 3.12 & 2.64 & 4.74 & 4.68 & 4.70 & 15.31 & 15.08 & 15.19 \\
\hline $\mathrm{I}_{3} \mathrm{C}_{1} \mathrm{~F}_{2}$ & 20.26 & 18.26 & 19.26 & 2.26 & 3.18 & 2.72 & 4.48 & 4.51 & 4.50 & 18.92 & 19.09 & 19.00 \\
\hline $\mathrm{I}_{3} \mathrm{C}_{1} \mathrm{~F}_{3}$ & 22.75 & 25.52 & 24.13 & 3.22 & 3.14 & 3.18 & 4.38 & 4.41 & 4.40 & 8.31 & 8.39 & 8.35 \\
\hline $\mathrm{I}_{3} \mathrm{C}_{2} \mathrm{~F}_{1}$ & 17.68 & 16.90 & 17.29 & 2.16 & 2.15 & 2.15 & 4.62 & 4.58 & 4.60 & 11.68 & 11.58 & 11.63 \\
\hline $\mathrm{I}_{3} \mathrm{C}_{2} \mathrm{~F}_{2}$ & 20.24 & 17.45 & 18.84 & 2.12 & 2.24 & 2.18 & 3.85 & 3.47 & 3.65 & 18.22 & 16.42 & 17.32 \\
\hline $\mathrm{I}_{3} \mathrm{C}_{2} \mathrm{~F}_{3}$ & 17.82 & 15.82 & 16.82 & 2.18 & 2.13 & 2.16 & 3.24 & 3.31 & 3.28 & 5.34 & 5.46 & 5.40 \\
\hline $\mathrm{S} . \mathrm{E}(\mathrm{m}) \pm$ & 0.28 & 0.25 & 0.18 & 0.03 & 0.03 & 0.02 & 0.06 & 0.06 & 0.04 & 0.17 & 0.17 & 0.12 \\
\hline C.D. $(0.05)$ & 0.80 & 0.72 & 0.51 & 0.09 & $\mathrm{NS}$ & 0.06 & 0.17 & 0.17 & 0.11 & 0.49 & 0.49 & 0.34 \\
\hline
\end{tabular}

$\mathrm{I}_{1}=15 \mathrm{CPE} ; \mathrm{I}_{2}=30 \mathrm{CPE} ; \mathrm{I}_{3}=45 \mathrm{CPE} ; \mathrm{F}_{1}=100 \% \mathrm{~N} / \mathrm{ha}$ from inorganic source; $\mathrm{F}_{2}=75 \% \mathrm{~N} / \mathrm{ha}$ from inorganic source $+25 \% \mathrm{~N} / \mathrm{ha}$ from organic source; $\mathrm{F}_{3}=50 \% \mathrm{~N} / \mathrm{ha}$ from inorganic source $+50 \% \mathrm{~N} / \mathrm{ha}$ from organic source; $\mathrm{C}_{1}=$ Sole crop; $\mathrm{C}_{2}=$ Intercrop. 
Table.3 Effect of levels of irrigation and fertility on plant height, number of pods per plant, pod weight and pod yield of French bean

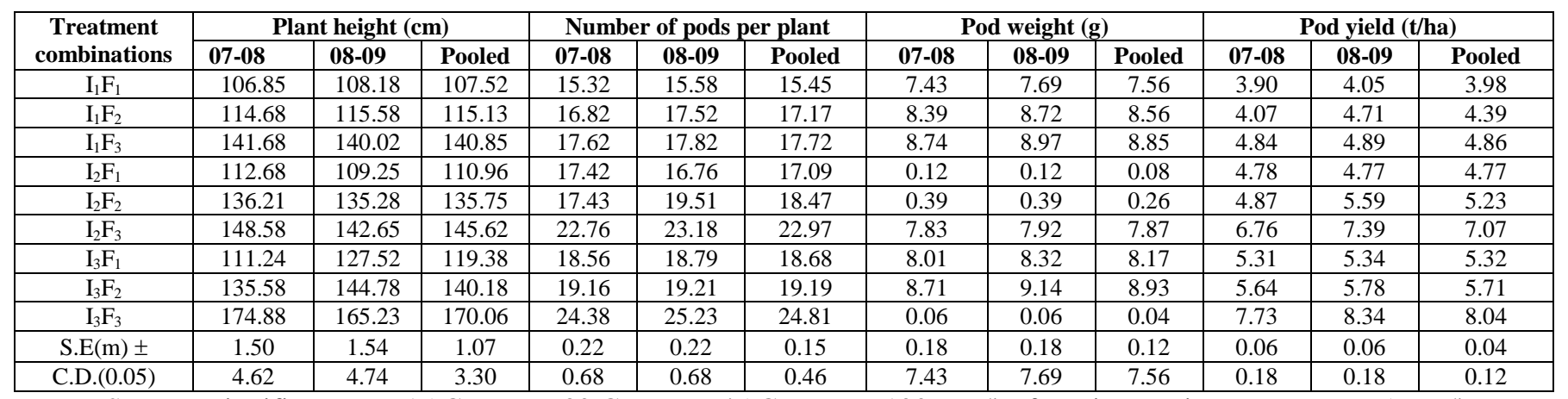

$\mathrm{NS}=$ Non significant; $\mathrm{I}_{1}=15 \mathrm{CPE} ; \mathrm{I}_{2}=30 \mathrm{CPE} ; \mathrm{I}_{3}=45 \mathrm{CPE} ; \mathrm{F}_{1}=100 \% \mathrm{~N} /$ ha from inorganic source $; \mathrm{F}_{2}=75 \% \mathrm{~N} / \mathrm{ha}$ from inorganic source $+25 \% \mathrm{~N} /$ ha from organic source; $\mathrm{F}_{3}=50 \% \mathrm{~N} / \mathrm{ha}$ from inorganic source $+50 \% \mathrm{~N} / \mathrm{ha}$ from organic source

Table.4 Effect of interactions of levels of irrigation and fertility on number of leaves per plant, root length, root weight and root yield of radish

\begin{tabular}{|c|c|c|c|c|c|c|c|c|c|c|c|c|}
\hline \multirow{2}{*}{$\begin{array}{c}\text { Treatment } \\
\text { combinations }\end{array}$} & \multicolumn{3}{|c|}{ number of leaves per plant } & \multicolumn{3}{|c|}{ Root length $(\mathrm{cm})$} & \multicolumn{3}{|c|}{ Root weight (g) } & \multicolumn{3}{|c|}{ Root yield (t/ha) } \\
\hline & 07-08 & 08-09 & Pooled & 07-08 & 08-09 & Pooled & 07-08 & 08-09 & Pooled & 2007-08 & 2008-09 & Pooled \\
\hline $\mathrm{I}_{1} \mathrm{~F}_{2}$ & 11.21 & 11.61 & 11.41 & 24.48 & 23.52 & 24.00 & 226.35 & 230.80 & 228.57 & 35.75 & 36.46 & 36.10 \\
\hline $\mathrm{I}_{2} \mathrm{~F}_{2}$ & 10.68 & 10.82 & 10.75 & 22.49 & 24.31 & 23.40 & 164.52 & 176.30 & 170.41 & 31.06 & 33.24 & 32.15 \\
\hline $\mathrm{I}_{2} \mathrm{~F}_{3}$ & 9.53 & 9.75 & 9.64 & 21.36 & 21.52 & 21.44 & 138.31 & 140.94 & 139.63 & 26.08 & 26.56 & 26.32 \\
\hline $\mathrm{I}_{3} \mathrm{~F}_{1}$ & 9.94 & 10.14 & 10.04 & 21.02 & 21.84 & 21.43 & 106.28 & 110.60 & 108.44 & 20.06 & 20.79 & 20.43 \\
\hline S.E $(m) \pm$ & 0.13 & 0.13 & 0.09 & 0.27 & 0.28 & 0.19 & 1.88 & 1.93 & 1.35 & 0.35 & 0.36 & 0.25 \\
\hline C.D.(0.05) & NS & NS & NS & 0.83 & NS & NS & 5.79 & 5.94 & 4.16 & 1.08 & 1.11 & 0.77 \\
\hline
\end{tabular}

$\mathrm{NS}=$ Non significant; $\mathrm{I}_{1}=15 \mathrm{CPE} ; \mathrm{I}_{2}=30 \mathrm{CPE} ; \mathrm{I}_{3}=45 \mathrm{CPE} ; \mathrm{F}_{1}=100 \% \mathrm{~N} /$ ha from inorganic source; $\mathrm{F}_{2}=75 \% \mathrm{~N} / \mathrm{ha}$ from inorganic source $+25 \% \mathrm{~N} /$ ha from organic source; $\mathrm{F}_{3}=50 \% \mathrm{~N} /$ ha from inorganic source $+50 \% \mathrm{~N} / \mathrm{ha}$ from organic source

Irrigation at $45 \mathrm{CPE}$ along with application of $120 \mathrm{~kg} \mathrm{~N} / \mathrm{ha}(50 \%$ from inorganic and $50 \%$ from organic sources) was found to be best for getting maximum plant height of $170.06 \mathrm{~cm}$ in French bean plant. Effect of interactions of irrigation and fertility was found to be significant on the results of number of pods per plant (Table 3). Data of individual years as well as their pooled values point out that maximum number of pods per plant were obtained with $\mathrm{I}_{3} \mathrm{~F}_{3}$ combination i.e. when the plots received 45 $\mathrm{CPE}$ level of irrigation along with $60 \mathrm{kgN} / \mathrm{ha}$ from inorganic and $60 \mathrm{kgN} / \mathrm{ha}$ from organic sources. Higher number of pods in French bean under integrated nutrient management had been reported earlier by Chaudhari et al., (2001).
Treatment combination $\mathrm{I}_{3} \mathrm{~F}_{3}$ resulted significant differences from other interactions during both the years. Effect of interactions of different levels of irrigation and fertility was significant on the results of pod weight of French bean during 2008-09 only (Table 3). Maximum pod weight of 9.25 and $9.86 \mathrm{~g}$ were obtained with $\mathrm{I}_{3} \mathrm{~F}_{3}$ combination. Influence of the said interaction was also reflected on the pooled values with the production of highest pod weight of $9.56 \mathrm{~g}$. Band et al., (2007) also established beneficial effects of integrated nutrient management on pod weight of French bean. It has been observed from the results of Table 4 that treatment combinations $\mathrm{I}_{1} \mathrm{~F}_{2}$ recorded root weight of radish. Effect of 
interactions of different levels of irrigation and fertility was found to be significant on pod yield per hectare in French bean when grown as an intercrop in the field of tomato (Table 3). Irrigation treatments associated with $\mathrm{F}_{3}$ level of fertility resulted better performances. Treatment combination $\mathrm{I}_{3} \mathrm{~F}_{3}$ recorded significantly highest pod yield of 7.73 and $8.34 \mathrm{t} /$ ha respectively in 2007-08 and 2008-09. The present results are in conformity with the findings of Ahlawat and Sharma (1998) who reported that seed yield of French bean was proportionately higher with reduced water supply as compared to seed yield with frequent irrigations. Next best result was obtained under $\mathrm{I}_{2} \mathrm{~F}_{3}$. Pooled data indicate that range of pod yield was between 3.98 and 8.04 t/ha. Higher pod yield might also be due to gradual and steady nutrient release during the growth period as well as enhanced biological activity and proper nutrition to the crop (Tripathy et al., 2004). Besides better vegetative growth associated with development of yield attributes and increased availability of plant nutrients might have resulted higher pod yield under $\mathrm{F}_{3}$ level of fertility. Similar results were also reported by Sharma and Arya (2001) in cabbage, Band et al., (2007) in French bean and Rathore et al., (2007) in cluster bean. The improvement in growth characters and yield attributes might have resulted enhanced pod yield under the promising combinations. During both the years of experiment minimum pod yield was recorded under $I_{1} F_{1}$.

\section{Effect of levels of irrigation and fertility level of radish}

Different treatment combinations of irrigation and fertility failed to influence significant effect on number of leaves per plant in both the years as well as on pooled data (Table 4). Maximum number of leaves of 11.21 and 11.61 were recorded with $\mathrm{I}_{1} \mathrm{~F}_{2}$ combination during 2007 08 and 2008 - 09. Pooled data show that maximum average number of leaves of 11.41 was also observed under $\mathrm{I}_{1} \mathrm{~F}_{2}$. The results are in conformity with the findings of Batra and Kalloo (1990) who also obtained increase root length of carrot with increase intensity of irrigation and Production of increased number of leaves of carrot at higher doses of inorganic $\mathrm{N}$.

Treatment $\mathrm{I}_{1} \mathrm{~F}_{2}$ combination produced maximum root length in both the years. Higher root length of radish at increasing level of nitrogen was reported earlier by Srinivas and Naik (1990). Treatment combinations namely, $\mathrm{I}_{1} \mathrm{~F}_{1}, \mathrm{I}_{2} \mathrm{~F}_{2}$ and $\mathrm{I}_{3} \mathrm{~F}_{2}$ were found to be promising for production of higher root length of radish in this experiment.

Effect of different treatment combinations of irrigation and fertility was found to be significant on individual root weight (Table 4). Maximum individual root weight of 226.35 and $230.80 \mathrm{~g}$ were obtained with $\mathrm{I}_{1} \mathrm{~F}_{2}$ combination in 2007-08 and 2008-09. Maximum root weight was $228.57 \mathrm{~g}$ in the pooled data. Treatment combination $\mathrm{I}_{1} \mathrm{~F}_{2}$ differed significantly from other interactions for the results of this character in both the years and in case of pooled values also. Minimum individual root weight was obtained with $\mathrm{I}_{3} \mathrm{~F}_{3}$. Effect of treatment combinations of irrigation and fertility was significant on root yield per hectare (Table 4). Maximum root yield of 35.75 and $36.46 \mathrm{t} / \mathrm{ha}$ were obtained with $\mathrm{I}_{1} \mathrm{~F}_{2}$ combination in first and second year. Highest pooled values of root yield was $36.10 \mathrm{t} / \mathrm{ha}$ and obtained with $\mathrm{I}_{1} \mathrm{~F}_{2}$ combination. Treatment combinations viz., $\mathrm{I}_{1} \mathrm{~F}_{1}$, $\mathrm{I}_{1} \mathrm{~F}_{3}$ and $\mathrm{I}_{2} \mathrm{~F}_{2}$ were also found to be promising for production of better root yield of radish.

\section{References}

Ahlawat, I.P.S. and Sharma, R.P. (1989). Response of French bean genotypes to soil moisture regimes and phosphate fertilization. Indian Journal of Agronomy, 34(1): 70-74.

Anonymous (2006). Indian Journal of Fertilizer, vol. 1(12): 9-10.

Band, A.M., Mendhe, S.N., Kolte, H.S., Choudhary, R.L., Verma, R. and Sharma, S.K. (2007). Nutrient management studies in French bean (Phaseolus vulgaris L.). Journal of Soils and Crops, 17(2): 367- 
372.

Batra, B.R. and Kalloo (1990). Effect of different levels of irrigation and fertilization on growth and yield of carrot (Daucus carota L.) for root production. Vegetable science, 17(2):127-139.

Chaudhari, C.S., Mendha, S.N., Pawar, W.S., Ingole, A.S. and Nikam, R.R. (2001). Nutrient management in French bean. Journals of Soils and Crops, 11(1): 137 139.

Gupta, C.R. and Sengar S.S. (2000). Response of tomato (Lycopersicon esculentum Mill.) to nitrogen and potassium fertilization in acidic soil of Bastar. Vegetable Science, 27(1): 94-95.

Harikrishna, B.L., Channel H.T., Hebsur, N.S, Dharmatti, P.R. and Sarangamath, P.A. (2002). Integrated nutrient management (INM) on availability of nutrients, uptake and yield of tomato. Karnataka Journal of Agricultural Science, 15(2): 275-278.

Kaur, H., Thakur, J.C. and Chawla, N. (2003). Effect of nitrogen and potassium on growth, yield and quality of tomato (Lycopersicon esculentum Mill) cv. Punjab Upma. Haryana Journal of Horticultural Science, 32(3- 4): 286-288.

National Horticulture Board, Indian Horticulture Data base, 2008.

Prakash, V., Pandey, A.K., Srivastava, A.K. and Gupta, H.S. (2004). Relay intercropping of hybrid tomato (Lycopersicon esculentum) in maize (Zea mays) under mid hill condition of North - Western Himalayas. Indian Journal of Agricultural Sciences, 74 (8) : 405 - 408.

Rafi Md., Narwadkar, P.R., Prabu, T. and Sajindranath, A.K. (2005). Effect of organic and inorganic fertilizers on growth and yield of tomato (Lycopersicon esculentum Mill.). South Indian Horticulture, 50(4-6): 522-526.

Rathore, V.S., Singh, J.P., Soni, M.L. and Beniwal, R.K. (2007). Effect of nutrient management on growth, productivity and nutrient uptake of rainfed clusterbean (Cyamopsis tetragonoloba) in arid region. Indian Journal of Agricultural Sciences, 77(6): 349-53.

Sahoo, D., Mahapatra, P., Das, A. K. and Sahoo, N.R. (2002). Effect of nitrogen and potassium on growth and yield of tomato (Lycopersicon esculentum) Var. UtKal Kumari. Haryana Journal of Horticultural Science, 31(3- 4): 264-266.

Sharda, R., Mahajan, G., Kaushal, M.P., Chawla, N. and Bal, S.S. (2006). Effect of irrigation on yield and quality of onion. Vegetable Science, 33(1): 34-37.

Sharma, K.C. and Arya, P.S. (2001). Effect of nitrogen and farmyard manure on cabbage (Brassica oleracea var capitata) in dry temperate zone of Himachal Pradesh. Indian Journal of Agricultural sciences, 71(1): 60-61.

Shukla, Y.R., Thakur, A.K. and Jhosi, A. (2009). Effect of inorganic and biofertilizers on yield and horticultural traits in tomato. Indian Journal of Horticulture, 66(2): 285-287.

Srinivas, K. and Naik, L.B. (1990). Growth and yield of radish (Raphanus Sativus L.) in relation to nitrogen and potash fertilization. Indian Journal of Hoticulture, 47(1): 114-119.

Tripathy, P., Bhattacharyay, B. and Maity, T.K. (2004). Response of okra (Abelmoschus esculentus L. Moench) to integrated nutrient management system. Orissa Journal of Horticulture, 32 (2): 14-18.

\section{How to cite this article:}

Yumnam, A., A.R. Mandal, T.M. Singh and Surbala Devi, N. 2017. Impact of Organic and Inorganic Sources of Nitrogen and Water Management on Tomato-French Bean by Radish Cropping System. Int.J.Curr.Microbiol.App.Sci. 6(12): 4110-4117. doi: https://doi.org/10.20546/ijcmas.2017.612.472 